\title{
MAGNETIC ROCKS — THEIR EFFECT ON COMPASS USE AND NAVIGATION IN TASMANIA
}

\author{
by David Leaman
}

\begin{abstract}
Leaman, D.E., 1997 (31:viii): Magnetic rocks - their effect on compass use and navigation in Tasmania. Pap. Proc. R. Soc. Tasm. 131:7375. https://doi.org/10.26749/rstpp.131.73 ISSN 0080-4703. Leaman Geophysics, GPO Box 320C, Hobart, Tasmania, Australia 7001.

The common and uncritical use of the magnetic compass by orienteers and walkers in Tasmania may lead to severe error. Rocks in many localities are intensely magnetised and their local field can strongly influence the pointing of a compass. Repeated observation against transect alignments may be necessary to minimise the problems.
\end{abstract}

Key Words: magnetics, compass, navigation, dolerite

\section{THE MAGNETIC FIELD}

The magnetic field in Tasmania has a normal intensity of about 61500 nanoteslas (nT) and is oriented upward at $71^{\circ}$ (inclination) and about $14^{\circ}$ east of north (declination). All values, especially declination, may change slowly with time. This is a strong field in global terms, and it should promote a stable compass, where the needle is properly compensated. The vertical component of this field is about $58150 \mathrm{nT}$ and the horizontal component about $20020 \mathrm{nT}$.

The orientation of the field in place means that, at the time of writing, any compass needle will point approximately $14^{\circ}$ east of true north when reading its own north. This value must be added to any compass reading in order to plot courses on a normal geographic base map.

If, however, the horizontal component of the field was rotated to another declination, then the compass needle would be swung away from the proper orientation for magnetic north across Tasmania. If the causative effect were local and the compass, or observer, were moving (as on a ship, aircraft or walking), then the compass needle might be observed to swing, be sluggish or rotate. These are common observations and often noted when the compass has been mounted in a vehicle and is clearly visible.

Either of two characteristics of the magnetic field is required if a compass, which is a relatively crude instrument, is to be affected. These are that the intensity of the field be increased substantially at a different declination - possibly very locally, or that there be abrupt changes in the orientation and magnitude of gradients in the local field. The first condition may arise from permanent magnetisation in the rocks present, while the second may be duc to local distribution or shape of rock exposures.

\section{SOME TASMANIAN ROCKS}

Most rocks are either permanently magnetised and/or magnetisable in the Earth's magnetic field. Very few, however, are magnetised, and most others are unable to induce a significant effect in the field. The magnetically important rocks - in a navigation context - include iron ores, ultramafics, and crucially (for Tasmania) basalts (mainly Tertiary in age) and the ubiquitous Jurassic dolerite.

Iron ores are restricted to small areas in northwestern Tasmania; near Savage River, Rocky River and Hampshire. Terrain in these regions is rarely cloud-bound and is sufficiently discinctive to ensure that any compass problems are not potentially life threatening. Ultramafic rocks, similarly, are relatively rare and of small volume but have been known to cause problems in isolated locations near Adamsfield, Andersons Creek (M. Banks, M. Brown, pers. comm.), Mclvors Hill (P.W. McCartney, pers. comm.), Heazlewood River and other localities as shown in figure 3.6 (p. 70) of the 1989 edition of the Geology and Mineral Resources of Tasmania, published by the Geological Society of Australia.

Basalt and dolerite are common rocks, and each may generate modest changes in the ambient field, due to their mineral content, which includes ilmenite and magnetite. A magnetic field may be affected by these minerals. These rocks rarely generate changes in excess of $1000 \mathrm{nT}$, and most occurrences do not modify the orientation of the field vector significantly. Dolerite is up to five times more magnetic than basalt, due to the minerals present, rock texture and crystal size. Both rocks are igneous and have crystallised from high temperature. The ambient magnetic field at the time of cooling (8-60 Ma for basalts and 160 $170 \mathrm{Ma}$ for dolerite) can be partially or wholly "frozen" into the rock, which may then act as a permanent magnet. This permanent or thermo-remanent effect may then be superimposed on the induction effect of the ambient field already acting on the minerals present. Thus, two magnetic field vectors may interact near such rocks. The net result depends on the strength of the remanent field and the amount of material which is susceptible to the present field. Weathering may destroy the permanent effect and change the capacity of the rock to induce a local field. A range of outcomes is possible and common. The compass needle responds to the total field actually generated.

Weathering of ferro-magnetic minerals may also produce weakly magnetic hydrous iron oxides (such as goethite, maghemite), and some ironstone gravels may be magnetic. Usually, however, these materials do not generate the intense effects required to deflect a compass needle.

Dolerite intrusions are usually large bodies, and significant compositional and textural changes may be observed within them. The most magnetic parts of the intrusions, in terms of induction effects, occur where crystals are large and much magetite is present. These conditions are usually found in the upper quarter of a sheet or near feeders. Most strong remanent effects, however, are related to the finergrained parts of the intrusions and are often confined to zones near contacts with either country rock or other 
intrusions (e.g. Leaman 1972). It is possible to generate anomalies of tens of thousands of nanoteslas in these conditions although 2000-5000 nT is more usual.

Compasses are not usually deflected greatly by this vector interplay, since the Jurassic and Tertiary magnetic fields were oriented much like the modern field - but with a steeper inclination - and the modern induction effect tends to swamp any permanent magnetisation present. The declination was not the same, however, and, consequently, if the intensity of the preserved field is high, then the remanence may dominate the magnetic properties of the rock. In such a case, that rock will twist the local field vector away from the present day magnetic north roward the preserved vector. Up to $40^{\circ}$ is possible for some dolerites (note data in Irving 1956, and Schmidt \& McDougal! 1977). Fortunately, this dominating condition appears to be quite rare and the shift is usually less than $5^{\circ}$. The remanent vector may sometimes oppose the modern vector (Leaman 1978) but, in most cases, it has a similar orientation, and the combination of vectors merely results in a decrease in local intensity.

Both rocks, however, occur on the land surface across wide areas, and a much more significant source of variation in their magnetic properties (especially for dolerite) is due to their elevated position in the landscape and the geometry of the exposures. Hill tops, promontories and many exposures on plateaux may have been struck by lightning on several occasions. A lightning strike generates a massive local electric current with considerable heating, and the associated transient magnetic field may entirely reset the normal magnetic properties of the rock. Since the currents may flow subhorizontally across the surface, the orientation of the field in the now reset, inrensely magnetised rock (a rock very susceptible ro such changes, due to its mineralogy) may be very different from the ambient field or extremely variable. The effect of a major lightning strike is permanent, and a large number of detectable and anomalous locations may exist across those parts of Tasmania where basalt or dolerite is exposed.

Many examples could be quoted of the type of changes observed. Four, including two new sites recorded by the author, are given to indicate the nature and scale of the effects possible.

(1) Rosny Hill, Hobart. Exposed rocky hill, dolerite. Heigh $100 \mathrm{~m}$ a.s.l. Several lightning strikes, each producing local changes with effect across radii up to $100 \mathrm{~m}$ (Watt 1971, Leaman 1972).

(2) Tasman Peninsula: Lichen Hill, north Tatnells Hill. Ridge line, sheltered col, little dolerite outcrop. Height $450 \mathrm{~m}$ a.s.l. Magnetic variaticn of north-up to $40^{\circ}$ over a ridge distance of $80 \mathrm{~m}$ at least.

(3) Mt Hull west, near Collinsvale. Ridge line, exposed dolerire rock outcrops. Height $750 \mathrm{~m}$ a.s.l. Magnetic variation of north-20 to $70^{\circ}$, depending on position among the outcrops. Affected area at least $16 \times 16 \mathrm{~m}$.

(4) Hartwell Cove south, near mouth of Wanderer River, western Tasmania. Area of Cambrian basalts. Chapman (1990: 110) has reported variations of $5^{\circ}$ to $25^{\circ}$ and advises that walkers avoid compass use in the area.

\section{COMPASS TECHNIQUE}

The examples suggest that problems leading to potentially serious errors might be endemic, given the common use of, or need to use, a compass - as in cloud on the central plateau (a dolerite area) or in dense forest.

Errors less than $5^{\circ}$ or $10^{\circ}$ may be serious in many situations; especially if a bearing is taken on a landmark, and then a route is traversed for some distance toward it before rechecking the bearing. Where visibility is restricted, it is more usual to continue observation of the compass, follow a bearing as displayed and to adjust the route continuously. In such cases, any local anomaly or distortion of bearing may not lead to a serious loss of position, unless there has been an unfortunate conjunction of observation sites and exposed, affected outcrops. Many such sites may exist on some ridges or hill tops (e.g. Lichen Hill or $\mathrm{Mt}$ Hull).

There is only one safe approach to compass navigation in all of central Tasmania and much of eastern and southeastern Tasmania. This is never to assume that the compass is reliable: continue to sight objects or trees and check the consistency of readings along transects (an alignment of two trees or features) for distance segments of at least 100-150 $\mathrm{m}$ - the longer the better. Since most intense anomalies have radii of influence less than $100 \mathrm{~m}$ they will be recognised and the background field orientation confirmed. Sightings from hill tops or bare rock exposures should be checked often.

\section{HISTORICAL ADDENDA}

Some historical notes may be added to this discussion.

Tasman recorded changes in his compass while sailing roward Mr Zeehan in 1642. His first observations were possibly near or beyond the edge of the continental shelf (Heeres 1985: 26); the needle was in motion. This is not readily explained in terms of geology, due to its position, but may indicate a magnetic storm or aurora. Two days later, he observed smaller changes in sight of land, a fact which so perturbed him and his crew that a vote was called, in order to decide whether to proceed, and the ship stood off that night (Heeres 1985). The inferred cause: Cambrian ultramafics on the continental shelf at a depth of about $60 \mathrm{~m}$. It may be noted here that some ultramafic rocks may influence a compass at a range of up to $1000 \mathrm{~m}$.

On 30-31 May 1804, Robert Brown climbed Mr Wellington (Brown 1804, Vallance 1990). He fell and sprained his foot at the summit. Whilst incapacitated, he undertook some magnetic observations with his compass and recorded in his diary that two stones (dolerite) right at the summit were able to generate swings of up to $180^{\circ}$. This influence, however, did not extend much more rhan $0.05 \mathrm{~m}$ from the surface of the rocks. This result might be considered the normal reaction of a compass to these rocks which, in typical circumstances where an observer is standing with the compass, might not have any notable influence.

Matthew Flinders also noted similar anomalies and compass deviations between Betsey Island and the Iron Pot, near the mouth of the River Derwent, during his exploratory surveys (Flinders 1814). It appears that the observations date from his 1798 cruise in the Norfolk. 
There is no published expansion of his notes, but the Australian Pilot $\left(1918,1\right.$ st ed., and $1969,5^{\text {th }} \mathrm{ed}$.) and all older charts (e.g. AUS 171, 794 pre 1975) locate the disturbance $3.2 \mathrm{~km}$ southeast of the Derwent Light, bearing $120^{\circ}$ true. Compass deflections between $17^{\circ}$ and $26^{\circ}$ have been recorded.

The area was resurveyed in 1973 and deviations of up to $25^{\circ}$ confirmed (Leaman 1975) in less than $20 \mathrm{~m}$ of water. Several features were defined and mapped (not one only, as marked on older charts), and most were associated with slightly shallower water, indicating some variation in seafloor structure or composition. Volcanic necks ( Tertiary basalts) exposed on the bay floor were inferred as the cause. The horizontal component in this zone is the dominant element of the magnetic field, and this accounts for sluggish compass responses and offset compass bearings. The check survey found that the main feature lay $1 \mathrm{~km}$ NNW of the officially charted cautionary note.

Any vessel crossing Storm Bay from the southeast, to clear the Iron Pot, could pass through the anomalous region. If a course of $300^{\circ}$ was held from south of Betsey Island, and the compass was the only navigational aid, then the possible deflection of $25^{\circ}$ would lead to a grounding at the west end of Hope Beach. The course actually run could lead, by following the compass, over at least two features, and the resultant deflection in course could be much greater.

Given this information, we may speculate about the contribution of magnetic effects to the wreck of the Hope in the early hours of Sunday, 29 April 1827. The events of that night have been recounted by O'May (1955), but some essential details may be summarised. The pilot boarded the vessel south of Betsey Island, at sunset, in light airs. The ship was making very little way. The night was very dark, and rain became heavy. Visibility was very poor. The ship had arrived in Storm Bay from Sydney and sailed directly into the anomalous zone, in order to clear the Iron Pot. The court of enquiry dwelled at length on the sobriety and competence of the pilot; the Captain had yielded the ship. The court assigned the cause of the wreck to a visual mistake - that of accepting the low profile of the neck beach for the river mouth, even though the pilot was said to be familiar with the area.

Perhaps there is an alternative explanation.

Flinder's observations may have been known in Hobart Town (as a result of comment by him in 1798 or later in Sydney), but it cannot be established that either the local pilot or the Captain of the Hope possessed knowledge of the feature or carried a chart bearing his warning. The records of enquiry make no comment about charts or warnings, and it is probable they were ignorant of the danger. This factor was not considered, or not considered relevant. The evidence adduced in court showed that the ship made very little way throughout the night, and that visibility was very poor at all times. The pilot would have known the required bearing to clear Cape Direction, having sighted this before sunset, and would have then held, conservatively, that bearing. It would have been about $300^{\circ}$. The beach and surf were not seen until the ship struck, not long before dawn. It is most unlikely that the pilot mistook any landforms - he probably saw none all night.

Suppose, however, the pilot (and the Captain on his nocturnal visits to the bridge) used the compass throughout. The vessel may then have been taken inexorably onto the beach. The very slow passage during the night could have contributed to the disaster, since all adjustments of the compass would have been subtle and imperceptible. Although this possible cause of the disaster is not mentioned in the official proceedings of the day, could it have been realised soon after? The Derwent Light was installed five years later, and the visual impact and guidance it afforded would then have obviated any further need for compass dependence in such conditions. Or was the construction of the light based on the belief that visual factors were the sole cause? The compass deflection explanation best accords with the recorded facts relating to that fateful night. There have been no subsequent wrecks in the area.

\section{REFERENCES}

BROWN, R., 1804: DIARY. Botany Library, British Museum of Natural History.

ChapMan, J., 1990: SOUTH WEST TASMANIA: A GUIDE BOOK FOR BUSHWALKERS. Chapman, 3rd edn: $192 \mathrm{pp}$.

FLINDERS, M., 1814: A VOYAGE TO TERRA AUSTRALIA ... IN HIS MAJESTY'S SHIP THE INVESTIGATOR. G.\& W. Nicol, London.

HeERES, J.E., 1985: THE DISCOVERY OF TASMANIA (24 November 1642). Extracts from the Journal of Abel Janszoon Tasman. Gov. Printer, Hobart.

IRVING, E., 1956: The magnetisation of the Mesozoic dolerites of Tasmania. Pap. Proc. Roy. Soc. Tasm. 90: 157-168.

Leaman, D.E., 1972: Rosny Matriculation College. Tech. Rep. Dep. Mines Tasm. 15: 102-106.

LeAman, D.E., 1975: Magnetic anomalies, Derwent Estuary and Storm Bay. Tech. Rep. Dep. Mines Tasm. 18: 55-59.

LEAMAN, D.E., 1978: Some thoughts on dolerite intrusions with particular reference to marginal features. Unpubl. Rep. Dep. Mines. Tasm. 1978/30.

O'MAY, H., 1955: WRECKS IN TASMANIAN WATERS. Tasm. Gov. Printer: 215 pp.

SCHMIDT, P.W. \& MCDougall, I., 1977: Palaeomagnetic and Potassium-Argon Dating Studies of the Tasmanian Dolerites. J. Geol. Soc. Aust. 24: 321-328.

ValLANCE, T.G., 1990: Botanicus in the Bush: Robert Brown's Australian Field-work, 1804-5. Proc. Linn. Soc. NSW 112(2): 49-86.

WaTT, C.J., 1971: Anomalous magnetisation in some Tasmanian igneous rocks. Unpubl. Hons thesis, Geol. Dep., Univ. Tasm.

(accepted 27 May 1997) 